\title{
Neuer Kursleiter
}

Unser Kursangebot wird Herr Prof. Dr. Philipp Klaritsch (MedUni Graz) im Bereich Gynäkologie / Geburtshilfe demnächst erweitern. Auf der letzten Vorstandssitzung hat er einen beeindruckenden Vortrag über „Besonderheiten monochorialer Zwillingsschwangerschaften und deren Management" gehalten, mit dem er sich als zukünftiger Kursleiter vorgestellt hat.

\section{E. Krampl-Bettelheim}

